\title{
Pengaruh Brand Image Produk Private Label Terhadap Kepuasan Pelanggan
}

\author{
Isyatin Amalianti $^{1 *}$ dan Ermina Tiorida ${ }^{2}$ \\ ${ }^{1}$ Jurusan Administrasi Niaga Politeknik Negeri Bandung, Indonesia \\ ${ }^{2}$ Jurusan Administrasi Niaga Politeknik Negeri Bandung, Indonesia
}

\begin{abstract}
:
The purpose of this research is to analyze how the influence of brand image on customer satisfaction. This research uses quantitave descriptive method. The sample in this study was 112 consumer of private label products (YOA) in Griya Supermarket Bandung, using nonprobability sampling - judgement sampling. The collection of information in this study was conducted by providing questionnaires to consumers and analyzed by using descriptive analysis, correlation, regression, coefficient of determination, and hypothesis testing. The results of this study indicate that the brand image affects customer satisfaction by $15 \%$ and the rest is influenced by other factors. Analysis results show that brand image has a positive effect on customer satisfaction.
\end{abstract}

Keywords: Brand image, customer satisfaction, Griya Supermarket Bandung, private label

\begin{abstract}
Abstrak :
Tujuan penelitian ini adalah menganalisisbagaimana pengaruh brand image terhadap kepuasan pelanggan. Metode penelitian ini menggunakan metode deskriptif. Sampel penelitian adalah 112 pelanggan yang menggunakan prodak "private label" yaitu YOA di Griya Supermarket Bandung dengan menggunakan non probability sampling - judgement. Teknik pengumpulan data dengan menggunakan kuisioner dan dengan menggunakan analisis deskriptif, korelasi, regresi, koofesien determinasi dan uji hipotesis. Hasil penelitian ini menunjukkan bahwa brand image berpengaruh terhadap kepuasan sebesar $15 \%$ dan sisannya di pengaruhi oleh faktor faktor lain. Hasil analisis menunjukkan bahwa brand image memiliki pengaruh yang positif terhadap kepuasan pelanggan.
\end{abstract}

Kata Kunci: gambaran merek, kepuasan pelanggan, Griya Supermarket Bandung, label privat

\section{PENDAHULUAN}

Pertumbuhan bisnis ritel di Indonesia pada tahun 2016 menurut Asosiasi Pengusaha Ritel Indonesia (Aprindo) mengalami peningkatan dari tahun sebelumnya, yakni menjadi $10 \%$ atau sekitar Rp 200 Triliun (Tribunnews.com, 2016). Masih dari sumber yang sama, peningkatan tersebut dikarenakan kondisi

\footnotetext{
*Email Korespondensi:

Isyatin Amalianti

IsyatinAmalianti@gmail.com
}

Jurnal Riset Bisnis \& Investasi

Vol. 3, No. 2, Agustus 2017

ISSN 2460-8211 makro ekonomi Indonesia yang semakin membaik karena pemerintah berhasil menekan tingkat inflasi ke level rendah yakni di bawah 4 persen. Hal ini terlihat dari daya beli masyarakat yang mulai membaik.

Perkembangan kebutuhan dan pola hidup masyarakat yang menginginkan pengelolaan secara profesional dan kenyamanan saat berbelanja merupakan salah satu faktor yang menyebabkan pertumbuhan ritel modern di Indonesia (Foster, 2008: 3). Perubahan gaya hidup 
dan kebiasaan berbelanja merupakan salah satu dampak dari terjadinya globalisasi. Globalisasi juga merupakan faktor utamaterciptanya permintaan barang dan jasa ritel (Sopiah \& Syihabudin, 2008: 121). Konsumen saat ini menginginkan tempat berbelanja yang aman, lokasinya mudah dicapai, ragam barang yang bervariasi, dan sekaligus dapat digunakan sebagai tempat rekreasi (Utami, 2006: 20).

Semakin banyaknya penduduk di suatu kota, maka semakin meningkat pula kebutuhan yang harus dipenuhi. Hal tersebut menyebabkan berkembangnya ritel modern seperti minimarket, supermarket, dan hypermarket di pemukiman penduduk. Berdasarkan data Dinas Koperasi UKM dan Perindustrian Perdagangan Kota Bandung tahun 2015, terjadi peningkatan pasar modern sebesar 1,07 persen dari tahun sebelumnya. Peningkatan pertumbuhan terjadi pada format supermarket dan hypermarket. Di Kota Bandung sendiri, hanya terdapat 2 perusahaan dengan format perseroan terbatas (PT) yang bergerak di bidang ritel modern dengan format supermarket, yaitu PT Akur Pratama denganoutlet bernama Toserba Griya dan PT Lion Super Indo dengan outlet bernama Superindo.

Toserba Griya merupakan salah satu supermarket yang memiliki outlet terbanyak di Kota Bandung dibandingkan dengan pesaingnya. Hal ini menyebabkan Toserba Griya lebih dikenal oleh konsumen. Menurut Suhendar (2011), supermarket Griya memiliki market share terbesar $(50 \%)$ dibandingkan supermarket lain, sedangkan Super Indo berada pada posisi kedua dengan market share sebesar 13,64\%. Hasil pra penelitian juga menunjukkan bahwa 19 dari 30 orang $(63,33 \%)$ menyatakan lebih tertarik untuk belanja di Toserba Griya dibandingkan dengan berbelanja di Super Indo. Konsumen di Kota Bandung beranggapan bahwa Toserba Griya merupakan supermarket yang menawarkan barang dengan kualitas produk yang baik dan harga yang terjangkau dibandingkan dengan pesaingnya.

Sejak tahun 2001 Yogya mengeluarkan produk dengan merek sendiri (private label) yaitu merek YOA. Strategi penetapan merek yang dikeluarkan oleh perusahaan sendiri dengan kemasan dan merek sendiri disebut dengan private label. Hingga saat ini, terdapat 29 produk Yoa yang ditawarkan kepada masyarakat. Hal ini merupakan salah satu strategi yang digunakan oleh Yogya Group untuk memenuhi kebutuhan konsumen (Tjandrasa, 2006). Selain itu, dengan memproduksi produk private label dapat menyebabkan margin perusahaan secara keseluruhan yang lebih baik sehingga meningkatkan keuntungan bagi perusahaan (Verhoef, dkk, 2002; Jaafar, et al, 2012; Dunne \& Narasimhan, 1999; Chen \& Liang C, 2009: 742; Cox \& Brittain, 2004: 120; dan Richardson, et al, 1996). Perusahaan juga dapat mengontrol harga, pengiriman dan kualitas produknya sendiri (Cox \& Brittain, 2004: 120). Sedangkan untuk konsumen dapat dijadikan sebagai produk alternatif untuk mendapatkan harga yang lebih rendah dibandingkan dengan manufacture's brand (Chen, \& Liang, C, 2009 dan Oxera, 2010).

Produk private label telah menjadi semacam trend di antara para peritel Indonesia, namun penggunaanya masih lebih rendah dibandingkan dengan manufacture's brand. Hal ini dikarenakan masyarakat Indonesia termasuk ke dalam kategori brand-loyal (Nielsen Global Survey, 2014). Sama seperti pendapat Kotler \& Amstrong (2004) yaitu manufacturers brand have long dominated the retail scene. Konsumen bisnis ritel di Indonesia terbiasa membeli produk dengan manufacture's brand dengan anggapan bahwa manufacture's brand lebih dapat dipercaya dibandingkan dengan private 
label. Pernyataan ini juga diperkuat dengan riset yang dilakukan oleh Nielsen Global Survey (2014) yaitu 65\% masyarakat Indonesia lebih percaya terhadap produk yang sudah ternama karena dianggap memiliki kualitas produk yang lebih baik. Hasil riset Nielsen sama dengan hasil pra penelitian yang menunjukkan bahwa $63,33 \%$ masyarakat merasa tidak percaya terhadap produk private label.

Salah satu produk private label yang belum sepenuhnya dipercaya oleh masyarakat adalah private label Yoa. Hasil pra penelitian menunjukkan bahwa $80 \%$ konsumen merasa tidak percaya terhadap produk private label Yoa. Di samping kualitas produk yang lebih rendah, citra merek produk private label Yoa belum sepenuhnya berada di benak konsumen. Konsumen belum merasa puas terhadap produk tersebut karena merek Yoa belum dikenal luas oleh masyarakat. Selain itu, konsumen juga merasa tidak puas dengan penampilan atau kemasan dari produk tersebut $(73,33 \%)$, seperti kemasan produk dan penyajian yang diberikan. Meskipun merek Yoa mudah diingat dan diucapkan dalam konsumen, namun kesan merek dibenak konsumen belum sesuai dengan harapan yang diinginkan konsumen. Hal ini tentu saja dapat berakibat pada kesuksesan merek tersebut, karena citra merek yang rendah akan lebih menghambat kesuksesan suatu produk dibandingkan produk dengan kualitas rendah (Zafar \& Rafique, 2011).

Citra merek memiliki peranan penting karena pelanggan selalu mencari produk atau jasa yang mereknya dapat bersaing di pasarnya (Neupane, 2015). Merek yang sesuai dengan harapan konsumen merupakan karakteristik dari merek yang sukses, karena konsumen percaya bahwa merek tersebut dapat diandalkan setelah produk digunakan (Neupane, 2015). Shahroudi \& Naimi (2014) menjelaskan bahwa merek yang sukses dapat meningkatkan kepercayaan konsumen dalam menggunakan produk ataupun jasa, sehingga pelanggan dapat memvisualisasikan dan mengidentifikasi produk yang diberikan. Peningkatan rasa percaya diri menandakan kepuasan konsumen terhadap produk yang dibelinya. Terciptanya kepuasan konsumen merupakan keberhasilan yang dicapai oleh perusahaan. Dengan menciptakan kepuasan pada konsumen dapat meningkatkan keuntungan dan memperluas pangsa pasar perusahaan. Berdasarkan latar belakang masalah yang telah diuraikan di atas, maka laporan penelitian ini berjudul Pengaruh Brand Image Produk Private Label terhadap Kepuasan Pelanggan.)

\section{KAJIAN LITERATUR \\ Bisnis Ritel}

Usaha ritel atau eceran merupakan kegiatan yang terlibat dalam penjualan barang atau jasa secara langsung kepada konsumen akhir bukan untuk dijual kembali melainkan untuk digunakan langsung (Utami, 2006: 4) dan merupakan mata rantai terakhir dalam penyaluran barang dari produsen sampai kepada konsumen (Sopiah \& Syihabudin, 2008: 7). Kotler \& Armstrong (2010: 394) juga menyebutkan bahwa retailing is all activities involved in selling goods or services directly to fianal consumers for their personal, nonbusiness use. Sopiah \& Syihabudin (2008: 38) menyatakan bahwa perdagangan eceran atau bisnis ritel diklasifikasikan menjadi dua kelompok besar, yaitu perdagangan eceran besar (specialty store, department store, supermarket, discount house, hypermarket, general store, dan chain store) dan perdagangan eceran kecil.

\section{Merek (Brand)}

Merek (brand) adalah nama, istilah, tanda, simbol atau rancangan atau kombinasi dari hal-hal tersebut dengan tujuan untuk mengidentifikasikan produk atau jasa yang dihasilkan agar berbeda dari 
produk atau jasa yang dihasilkan oleh pesaing (Rangkuti, 2004: 243). Sedangkan Riezobos (2003: 63) menjelaskan a brand is every sign that is capable of distinguishing the goods or services of a company and that can have a certain meaning for consumers both in material and inmaterial item. Shahroudi \& Naimi (2014: 27) berpendapat bahwa brand is a symbol or a sign that will help customer to identify a product.

\section{Private Label}

Kotler \& Amstrong (2008) berpendapat bahwa private brands is brands that made by own retailers or wholesale. Merek pribadi atau private label adalah nama atau merek yang diproduksi sendiri oleh peritel. Penggunaan private label merupakan solusi terbaik untuk meningkatkan nilai perusahaan di mata konsumen (Bozhinoz, 2013: 32). Para peritel perlu mengetahui manfaat yang akan didapatkan dari private brand/label, seperti:

1) Menyebabkan marjin perusahaan secara keseluruhan menjadi lebih baik atau lebih tinggi (Dunne \& Narasimhan, 1999; Chen \& Liang C, 2009: 742; Cox \& Brittain, 2004: 120).

2) Dapat meningkatkan loyalitas dan citra toko (Chen \& Liang C, 2009: 742; Liu \& Wang, 2008; Labeaga, et al., 2007; dan Abril \& Canovas, 2016: 168). Hal ini dikarenakan pengecer menjual produk yang tidak dapat dibeli dari pesaing (Chen \& Liang C., 2009: 742). Sementara merek manufaktur (manufacture brands) tersedia di banyak gerai pesaing (Labeaga, et al., 2007).

3) Dapat membangun hubungan yang kuat dengan konsumen (Abril \& Canovas, 2016: 168) serta menciptakan loyalitas konsumen (Bozhinova, 2013: 31).

4) Meningkatkan persaingan antar pengecer, sehingga tiap pengecer perlu melakukan inovasi untuk dapat bertahan dalam persaingan, misalnya dengan memberikan dimensi tambahan untuk menarik konsumen seperti memberikan kemasan dan promosi yang menarik serta menawarkan potongan harga (Oxera, 2010: 13).

5) Sebagai strategi untuk meningkatkan diferensiasi dan positioning antar pengecer (Abril \& Canovas, 2016: 168).

6) Perusahaan dapat mengontrol harga, pengiriman dan kualitas produknya sendiri (Cox \& Brittain, 2004: 120)

7) Meningkatkan hubungan antara pengecer dan pemasok, karena keduanya ingin memberikan produk yang diminati konsumen (Oxera, 2010: 13 dan Dunne \& Narasimhan, 1999). Pengecer mengetahui informasi mengenai produk yang sedang diminati konsumen melalui tingkat penjualan produk (slow moving atau fast moving). Sedangkan pemasok yang menyediakan produk yang diminati konsumen kepada pengecer. Sehingga terjadi pertukaran informasi antara pengecer dan pemasok.

\section{Citra Merek (Brand Image)}

Brand image is consumer's perception about a brand, as reflected by the brand associations held in consumer memory (Keller, 1993: 3). Persepsi terbentuk berdasarkan pengalaman pribadi konsumen, baik pengalaman positif maupun pengalaman negatif (Simanjuntak, 2012:16). Sedangkan Suhartanto (2008: 36) menjelaskan bahwa citra merek merupakan kesan yang dimiliki oleh konsumen terhadap suatu merek. Keller (1993:5) mengatakan bahwa terdapat tiga komponen citra merek (brand image), yaitu strength of brand associations, favorability of brand associations, dan uniqueness of brand associations.

- Strength of brand association tergantung pada bagaimana informasi 
masuk ke dalam ingatan konsumen dan bagaimana merek tersebut dapat bertahan sebagai bagian dari citra merek. Yang termasuk keunggulan merek adalah penampilan fisik, fasilitas pendukung produk seperti promosi, harga produk, dan fungsi dari fasilitas produk.

- Favorability of brand association dimana konsumen percaya bahwa atribut dan manfaat yang diberikan oleh merek dapat memenuhi kebutuhan dan keinginan konsumen sehingga konsumen membentuk sikap positif terhadap merek.

- Uniqueness of brand association merupakan kemampuan membedakan merek diantara merek lainnya. Hal ini muncul akibat dari kesan pelanggan terhadap atribut yang terdapat pada produk. Yang termasuk kedalam kategori keunikan adalah variasi harga, penampilan atau nama dari sebuah merek, dan fisik produk.

\section{Kepuasan Pelanggan}

Kepuasan pelanggan adalah sejauh mana anggapan kinerja produk atau jasa memenuhi harapan pembeli (Kotler, 2005). Mowen dan Minor (2002) berpendapat bahwa kepuasan pelanggan adalah keseluruhan sikap yang ditunjukkan konsumen atas barang atau jasa setelah mereka memperoleh dan menggunakannya. Ini merupakan penilaian evaluatif pasca pemilihan yang disebabkan oleh seleksi pembelian khusus dan pengalaman menggunakan/ mengkonsumsi barang atau jasa tersebut. Pihak yang paling banyakberhubungan langsung dengan kepuasan atau ketidakpuasan pelanggan adalah pemasar, konsumen, dan peneliti perilaku konsumen (Tjiptono, 2005).

Pada dasarnya kepuasan pelanggan merupakan suatu hal mendasar yang harus dipenuhi oleh perusahaan dalam proses mempertahankan pelanggan guna membentuk loyalitas pelanggan pada produk maupun jasa yang dijual oleh perusahaan. Perusahaan akan bertindak bijaksana dengan mengukur kepuasan pelanggan secara teratur (Kotler \& Keller, 2009: 110). Pengukuran terhadap kepuasan pelanggan perlu diperhatikan bagi setiap perusahaan, karena pengukuran dapat memberikan umpan balik dan masukan bagi keperluan pengembangan dan implementasi strategi peningkatan kepuasan pelanggan.

Pengukuran yang banyak digunakan untuk mengukur kepuasan adalah teori ketidakcocokan/diskonfirmasi (disconfirmation). Konsep Diskonfirmasi Harapan yang paling dikenal adalah model yang dikembangkan oleh Richard L. Oliver. Oliver (1980) menyatakan bahwa konsumen memiliki harapan tertentu (ekspektasi) terhadap produk yang dibeli atau digunakan. Peter \& Olson (2000: 158) menjelaskan bahwa ketidakcocokan (disconfirmation) adalah perbedaan antara harapan pra pembelian dan persepsi pasca pembelian.

Harapan pra pembelian dapat dipenuhi ketika kinerja produk sesuai dengan apa yang diharapkan ataupun sebaliknya. Penilaian kepuasan pelanggan terbagi kedalam tiga kelompok (Oliver, 1980: 461), yaitu:

1. Diskonfirmasi positif artinya kinerja lebih baik daripada yang diharapkan (persepsi > ekspektasi), menghasilkan respon kepuasan

2. Konfirmasi Sederhana artinya kinerja sama dengan yang diharapkan (persepsi $=$ ekspektasi), menyiratkan respon yang lebih netral, tidak positif atau negatif

Diskonfirmasi negatif artinya kinerja lebih buruk daripada yang diharapkan (persepsi < ekspektasi), menghasilkan respon ketidakpuasanEngel, et al (1995: 212) mengatakan bahwa hasil dari teori diskonfirmasi dapat secara langsung 
mempengaruhi niat pembelian ulang, semakin besar diskonfirmasi positifnya, maka semakin baik.

\section{Kerangka Pemikiran}

Meningkatnya persaingan dalam pasar ritel modern menyebabkan peritel harus memiliki strategi untuk memenangkan persaingan. Salah satu strategi yang dapat digunakan adalah mengeluarkan produk dengan merek sendiri (private label). Banyak manfaat yang didapatkan apabila peritel melakukan strategi tersebut, seperti dapat menyebabkan margin perusahaan secara keseluruhan menjadi lebih baik sehingga meningkatkan keuntungan bagi perusahaan (Verhoef, dkk, 2002; Jaafar, et al, 2012; Dunne \& Narasimhan, 1999; Chen \& Liang C, 2009: 742; Cox \& Brittain, 2004: 120; dan Richardson, et al, 1996). Selain itu, perusahaan juga dapat mengontrol harga, pengiriman dan kualitas produknya sendiri (Cox \& Brittain, 2004: 120). Sedangkan untuk konsumen, produk dengan private label dapat dijadikan sebagai produk alternatif untuk mendapatkan harga yang lebih rendah dibandingkan dengan manufacture's brand (Chen, \& Liang, C, 2009 dan Oxera, 2010).

Penggunaan produk private label masih lebih rendah dibandingkan dengan manufacture's brand. Konsumen masih beranggapan bahwa produk private label hanya sebagai alternatif kedua setelah manufacture's brand. Selain itu, citra merek produk private label masih belum sepenuhnya berada dalam benak konsumen. Padahal citra merek memiliki peranan penting karena pelanggan selalu mencari produk atau jasa yang mereknya dapat bersaing di pasarnya (Neupane, 2015).

Citra merek yang baik juga menjadi salah satu pertimbangan konsumen dalam memilih produk. Bila sebuah merek telah dikenal luas di pasaran, perusahaan tidak memerlukan usaha lebih untuk mempertahankan brand-nya. Konsumen lebih mempercayai produk dengan merek tertentu daripada produk tanpa merek meskipun manfaat yang ditawarkan serupa. Ketika konsumen menggunakan merek tertentu, secara otomatis konsumen akan terhubung dengan merek tersebut artinya konsumen akan membawa serta citra dari pengguna sekaligus karakteristik merek itu sendiri. Merek yang sesuai dengan harapan konsumen dan dapat diandalkan setelah produk digunakan juga menjadi kriteria dari merek yang sukses (Neupane, 2015). Tanpa Citra Merek yang positif dan kuat, perusahaan tidak bisa mendapatkan sebagian besar pangsa pasarnya. Persepsi pelanggan mengenai citra merek sangat penting dan dapat menentukan keberhasilan atau kegagalan dalam bisnis (Mirzai, et al, 2016: 52).

Untuk membentuk citra merek yang baik, perusahaan perlu memperhatikan komponen-komponen pembentuk citra merek. Dimensi brand image menurut Keller (1993) adalah strength of brand association, favorability of brand association dan uniqueness of brand association. Kekuatan asosiasi merek (strength of brand association) didapatkan dari informasi konsumen mengenai brand attribute dan brand benefit (Keller, 1993: 4). Untuk favorability of brand association tergantung pada kepercayaan konsumen bahwa brand attribute dan brand benefit dapat memenuhi kebutuhan dan keinginan konsumen (Keller, 1993: 5 dan Ferrinadewi, 2008). Untuk keunikan asosiasi merek (uniqueness of brand association) dapat bergantung pada kelebihan yang dimiliki oleh merek sehingga dapat bersaing secara terus menerus dan menjadi salah satu alasan bagi konsumen untuk membeli merek tersebut (Keller, 1993: 6). Selain itu keunikan asosiasi merek (uniqueness of brand association) juga bergantung pada keyakinan bahwa merek tersebut memiliki 
perbedaan dibandingkan merek lainnya.

Menciptakan brand yang kuat dan positif dapat membuat konsumen merasa dan berpikir bahwa produk atau layanan yang ditawarkan lebih baik daripada pesaingnya (Andreani, 2012: 63). Kuatnya brand image di benak konsumen akan menyebabkan semakin kuat rasa percaya diri yang dirasakan oleh konsumen dalam menggunakan produk yang dibelinya. Peningkatan rasa percaya diri menandakan kepuasan terhadap produk yang dibelinya.

Kepuasan pelanggan adalah sejauh mana anggapan kinerja produk memenuhi harapan pembeli atau pelanggan. Kepuasan pelanggan terdiri dari dua dimensi, (1) tingkat harapan atau ekspektasi pelanggan terhadap kinerja produk, dan (2) persepsi pelanggan terhadap kinerja aktual produk (Tjiptono, 2006). Dengan membangun citra merek yang baik, pelanggan cenderung meningkatkan kepuasan penggunaan, dan ingin merekomendasikan kepada orang lain (Aaker, 1991). Hal tersebut selaras dengan beberapa penelitian terdahulu yang mengemukakan bahwa terdapat hubungan positif antara citra merek (brand image) dan kepuasan pelanggan (Neupane, 2015; Rivai \& Wahyudi, 2017; Shahroudi \& Naimi, 2014; Malik, et al, 2012; Hsiung, 2011; dan Sondoh, et al, 2007).

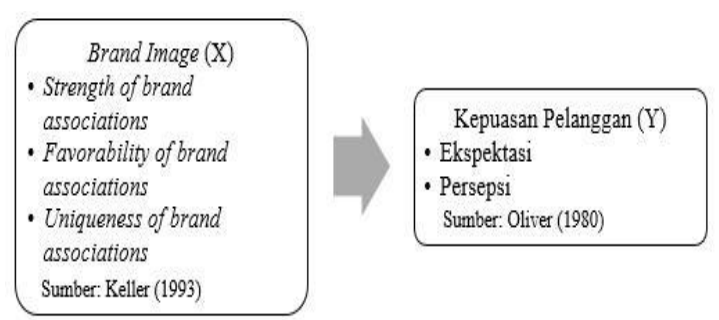

Gambar 1 Kerangka Pemikiran

Sumber: Olahan Penulis, 2017

Gambar 1 menjelaskan bahwa terdapat hubungan antara citra merek (brand image) dan kepuasan pelanggan. Variabel brand image $(x)$ terdiri dari tiga dimensi yaitu strength of brand associations, favorability of brand associations, dan uniqueness of brand associations (Keller, 1993). Sedangkan untuk variabel kepuasan pelanggan, dimensi yang digunakan adalah menurut pendapat Oliver (1980) yaitu ekspektasi dan persepsi. Berdasarkan pembahasan dalam latar belakang, landasan teori, dan kerangka berpikir, hipotesis penelitian ini adalah sebagai berikut:

Ho : Tidak terdapat pengaruh antara brand image produk private label Yoa terhadap kepuasan pelanggan Toserba Griya Kota Bandung.

$\mathrm{Ha}$ : Terdapat pengaruh antara brand image produk private label Yoa terhadap kepuasan pelanggan Toserba Griya Kota Bandung.

\section{METODE PENELITIAN}

Metode yang digunakan dalam penelitian ini adalah deskriptif kuantitatif. Metode ini bertujuan untuk mengetahui pengaruh brand image terhadap kepuasan pelanggan.

\section{Populasi dan Metode Penarikan Sampel}

Anggota populasi dalam penelitian ini adalah konsumen Toserba Griya di Kota Bandung. Metode penarikan sampel yang digunakan adalah nonprobability sampling - judgement sampling. Sampel yang digunakan dalam penelitian ini adalah konsumen yang pernah membeli produk private label YOA minimal 2 kali pembelian selama 3 bulan terakhir. Jumlah sampel yang digunakan dalam penelitian ini adalah menurut Voorhis \& Morgan (2007: 48) yaitu N > 105. Sehingga, penelitian ini menggunakan sampel berjumlah 112 responden dengan pembagian masing-masing 16 responden di setiap Toserba Griya.

\section{HASIL DAN PEMBAHASAN Analisis Deskriptif}

Berdasarkan tabel 1, jawaban responden pada variabel brand image berada pada rentang 2 hingga 4, dimana 
jawaban responden terendah adalah 2 dan tertinggi adalah 4. Nilai rata-rata (mean) variabel brand image yaitu 2,60. Hal tersebut menandakan bahwa brand image produk Yoa berada pada kategori rendah atau buruk karena berada pada interval 1,81 $-2,60$. Nilai standar deviasi variabel brand image sebesar 0,351 atau $13,5 \%$ yang didapat dari perhitungan: ${ }^{0,351}{ }_{2,60} \times 100 \%$. Nilai tersebut menunjukkan bahwa variasi jawaban kecil dan sebagian besar responden menjawab pernyataan variabel ini dengan jawaban yang relatif sama karena nilai standar deviasi variabel brand image berada di bawah $20 \%$.

Tabel 1 Deskriptif Brand Image

\begin{tabular}{|l|r|r|l|l|l|}
\hline & N & $\begin{array}{c}\text { Minim } \\
\text { um }\end{array}$ & $\begin{array}{c}\text { Maxi } \\
\text { mum }\end{array}$ & Mean & $\begin{array}{c}\text { Std. } \\
\text { Deviaton }\end{array}$ \\
\hline Brand_Image & 112 & 2 & 4 & 2.60 & .351 \\
\hline $\begin{array}{l}\text { Valid N } \\
\text { (listwise) }\end{array}$ & 112 & & & & \\
\hline
\end{tabular}

Sumber: Olah Data SPSS (2017)

Tabel 2 Deskriptif Kepuasan Pelanggan

\begin{tabular}{|l|r|c|c|c|c|}
\hline & N & Minimum & Maximum & Mean & $\begin{array}{c}\text { Std. } \\
\text { Deviation }\end{array}$ \\
\hline $\begin{array}{l}\text { Kepuasan_P } \\
\text { elanggan } \\
\text { Valid N } \\
\text { (listwise) }\end{array}$ & 112 & 1 & 5 & 2.77 & .454 \\
\hline
\end{tabular}

Sumber: Olah Data SPSS (2017)

Berdasarkan tabel 2, total jawaban responden pada variabel kepuasan pelanggan berada pada rentang 1 hingga 5, dimana jawaban responden terendah adalah 1 dan tertinggi adalah 5. Nilai rata-rata (men) variabel kepuasan pelanggan yaitu 2,77. Hal tersebut menandakan bahwa kepuasan pelanggan produk Yoa berada pada kategori cukup karena berada pada interval 2,61 - 3,40. Nilai standar deviasi variabel kepuasan pelanggan sebesar 0,454 atau $16,39 \%$ yang didapat dari perhitungan:

$$
\frac{0,454}{2,77} \times 100 \%
$$

Nilai tersebut menunjukkan bahwa variasi

Jurnal Riset Bisnis \& Investasi

Vol. 3, No. 2, Agustus 2017

ISSN 2460-8211 jawaban kecil dan sebagian besar responden menjawab pernyataan variabel ini dengan jawaban yang relatif sama karena nilai standar deviasi variabel kepuasan pelanggan berada di bawah $20 \%$.

\section{Analisis Korelasi}

Berdasarkan tabel 3, nilai pearson correlation antara variabel brand image dan kepuasan pelanggan adalah 0,387 dengan arah hubungan positif. Artinya, hubungankedua variabel bersifat searah, yaitu jika variabel brand image mengalami kenaikan, maka variabel kepuasan pelanggan juga mengalami kenaikan. Nilai korelasi tersebut berada pada rentang $+0,30$ s/d + 0,49 (Bungin, 2013), yang artinya bahwa terdapat hubungan positif yang sedang antara variabel brand image dan kepuasan pelanggan. Selain itu, hubungan antara brand image dan kepuasan pelanggan memiliki nilai signifikansi sebesar 0,000 yang artinya korelasi tersebut signifikan karena nilai sig $<0,05$.

Tabel 3. Uji Korelasi Sederhana

\begin{tabular}{|c|c|c|c|}
\hline & & $\begin{array}{l}\text { Brand } \\
\text { Image }\end{array}$ & $\begin{array}{l}\text { Kepuasan } \\
\text { Pelanggan }\end{array}$ \\
\hline \multirow{3}{*}{ Brand Image } & $\begin{array}{l}\text { Pearson } \\
\text { Correlation }\end{array}$ & 1 & $.387^{* *}$ \\
\hline & $\begin{array}{l}\text { Sig. } \\
\text { (2-tailed) }\end{array}$ & & .000 \\
\hline & $\mathrm{N}$ & 112 & 112 \\
\hline \multirow{3}{*}{$\begin{array}{l}\text { Kepuasan } \\
\text { Pelanggan }\end{array}$} & $\begin{array}{l}\text { Pearson } \\
\text { Correlation }\end{array}$ & $387^{* *}$ & 1 \\
\hline & $\begin{array}{ll}\text { Sig. } & (2 \\
\text { tailed })\end{array}$ & .000 & \\
\hline & $\mathrm{N}$ & 112 & 112 \\
\hline
\end{tabular}

Sumber: Olah data SPSS (2017)

Tabel 4. Uji Regresi Linier Sederhana

\begin{tabular}{|l|c|l|l|l|l|}
\hline \multirow{2}{*}{ Model } & \multicolumn{2}{|c|}{$\begin{array}{c}\text { Unstandardized } \\
\text { Coefficients }\end{array}$} & $\begin{array}{c}\text { Standa } \\
\text { rdized } \\
\text { Coeffi } \\
\text { cients }\end{array}$ & \multirow{2}{*}{$\mathrm{t}$} & Sig. \\
\cline { 2 - 4 } & $\mathrm{B}$ & $\begin{array}{c}\text { Std. } \\
\text { Error }\end{array}$ & Beta & & \\
\hline (Constant) & 8.535 & 1.849 & & 4.617 & .000 \\
\hline Brand Image & 309 & .070 & .387 & 4.408 & .000 \\
\hline
\end{tabular}




\section{Analisis Regresi Linier Sederhana}

Analisis regresi yang digunakan adalah analisis regresi linier sederhana (simple linear regression analysis).

Dapat dilihat pada Tabel 1 kolom Unstandardized Coefficients, nilai konstanta (a) sebesar 8,535 dengan koefisien regresi (b) sebesar 0,309. Maka diperoleh persamaan regresi linear sederhana $\mathrm{Y}=8,535+0,309 \mathrm{X}$.

Nilai a dan b di atas dapat diinterpretasikan sebagai berikut:

Konstanta (a) sebesar 8,535 dapat diartikan jika brand image nilainya sama dengan nol $(\mathrm{X}=0)$, maka nilai kepuasan pelanggan nilainya positif 8,535 .

Koefisien regresi (b) variabel brand image sebesar 0,309 yang artinya jika brand image mengalami kenaikan satu satuan maka kepuasan pelanggan akan mengalami kenaikan sebesar 0,309 satuan. Koefisien bertanda positif artinya terjadi hubungan positif antara brand image dankepuasan pelanggan. Hal ini menunjukkan bahwa apabila brand image meninngkat di mata konsumen, maka kepuasan pelanggan pun akan meningkat.

\section{Koefisien Determinasi}

Koefisien determinasi ini berfungsi untuk mengetahui persentase besarnya pengaruh variabel independent dan variabel dependent. Koefisien determinasi dapat dilihat pada tabel 5 .

Tabel 5 Koefisien Determinasi

\begin{tabular}{|l|l|l|l|l|}
\hline Model & R & R Square & $\begin{array}{c}\text { Adjusted R } \\
\text { Square }\end{array}$ & $\begin{array}{c}\text { Std. Error } \\
\text { of the } \\
\text { Estimate }\end{array}$ \\
\hline 1 & $.387^{\mathrm{a}}$ & 150 & .142 & 2.521 \\
\hline
\end{tabular}

Sumber: Olah Data SPSS (2017)

Pada tabel 5, nilai koefisien determinasi ( $\mathrm{R}$ square $/ \mathrm{R}^{2}$ ) adalah angka korelasi yang dikuadrakan atau $0,387^{2}$ sebesar 0,150 atau $15 \%$. Nilai tersebut menunjukkan bahwa brand image berpengaruh sebesar $15 \%$ terhadap kepuasan pelanggan. Sementara sisanya
(85\%) dipengaruhi oleh faktor-faktor lain yang tidak diteliti dalam penelitian ini. Rendahnya nilai $\mathrm{R}$ square (15\%) menunjukkan bahwa variabel brand image memiliki pengaruh yang rendah terhadap kepuasan pelanggan.

\section{UJI HIPOTESIS}

\section{Uji Signifikansi Simultan (Uji F)}

Uji F dilakukan untuk mengetahui apakah model regresi linier yang digunakan sudah tepat atau belum. Hasil uji statistik F dilihat pada tabel 1.6.

Tabel 6 Uji Statistik F

\begin{tabular}{|c|l|l|l|l|l|}
\hline Model & $\begin{array}{l}\text { Sum of } \\
\text { Squares }\end{array}$ & df & $\begin{array}{l}\text { Mean } \\
\text { Square }\end{array}$ & F & Sig. \\
\hline $\begin{array}{c}\text { Regressi } \\
\text { on } \\
1 \begin{array}{c}\text { Residual } \\
\text { Rotal }\end{array}\end{array}$ & 123.455 & 1 & 123.455 & 19.427 & $\begin{array}{l}.000 \\
\text { b }\end{array}$ \\
\hline
\end{tabular}

Sumber: Olah Data SPSS (2017)

Berdasarkan tabel 1.6, dapat dilihat bahwa nilai $\mathrm{F}$ hitung (F0) brand image terhadap kepuasan pelanggan adalah sebesar 19,427 . Untuk nilai $F$ tabel harus memperhatikan hal berikut: 1) Signifikansi $=0,05.2) \mathrm{df} 1=1.3) \mathrm{df} 2=110$.

Dari hasil perhitungan, maka diperoleh hasil $\mathrm{f}$ tabel $(\mathrm{Ft})$ dengan signifikansi 0,05 yaitu sebesar 3,93. Dengan demikian nilai $\mathrm{F}$ hitung lebih besar dari $\mathrm{F}$ tabel yaitu 19,427 > 3,93 dengan nilai signifikansi/probabilitas sebesar 0,000 . Hal tersebut menunjukkan bahwa Ho ditolak dan $\mathrm{Ha}$ diterima. Dapat disimpulkan bahwa brand image produk YOA berpengaruh secara signifikan terhadap kepuasan pelanggan di Toserba Griya Kota Bandung.

\section{Uji Statistik T}

$$
\text { Uji statistik } t \text { pada dasanya }
$$


menunjukkan seberapa jauh pengaruh suatu variabel independent atau bebas secara individual dalam menerangkan variabel dependent atau terikat.

Berdasarkan tabel 7 , nilai t hitung brand image terhadap kepuasan pelanggan adalah 4,408. Sedangkan t tabel dengan: Signifikansi $=0,05$ dan Df $=110$. Maka diperoleh $\mathrm{t}$ tabel sebesar 1,982 yang berarti bahwa $\mathrm{t}$ hitung > $\mathrm{t}$ tabel $(4,408>1,982)$. Nilai signifikansi/probabilitas adalah sebesar 0,000, maka nilai probabilitas lebih kecil dari 0,05 ( 0,000<0,05). Hasil tersebut menunjukkan bahwa Ho ditolak dan Ha diterima. Dapat disimpulkan bahwa brand image produk YOA berpengaruh secara signifikan terhadap kepuasan pelanggan di Toserba Griya Kota Bandung.

Tabel 7 Hasil Uji Statistik t

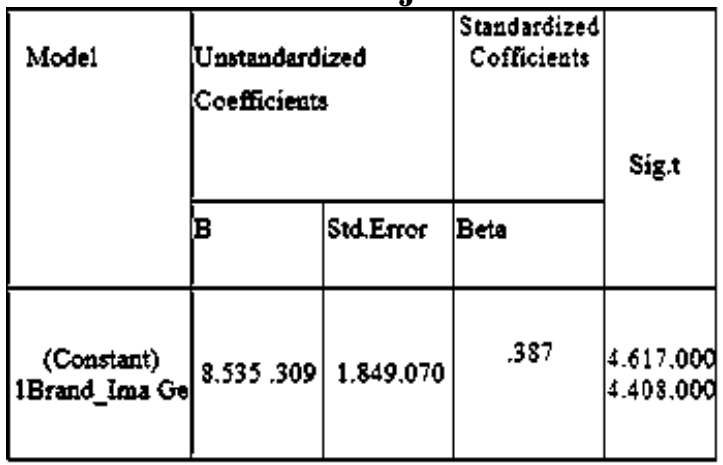

Sumber: Olah Data SPSS (2017)

\section{Pengaruh Brand Image Terhadap Kepuasan Pelanggan}

Berdasarkan data demografi responden yang merupakan konsumen produk YOA, dapat diketahui bahwa mayoritas konsumen produk YOA adalah perempuan yaitu sebanyak 83 orang $(74,2 \%)$. Hal ini dikarenakan, perempuan lebih sering melakukan pembelian bahan makanan dan minuman kebutuhan seharihari dan peralatan rumah tangga lainnya. Produk YOA lebih cocok untuk konsumen perempuan karena konsumen perempuan cenderung membandingkan harga suatu produk saat melakukan pembelian. Konsumen produk private label YOA didominasi oleh kalangan usia 26-35 tahun yaitu sebanyak 37 orang (33\%). Hal ini dikarenakan, jenis produk YOA biasa digunakan untuk kebutuhan rumah tangga. Untuk jenis pekerjaan PNS memiliki persentase terendah yaitu $1,79 \%$, alasannya karena pengambilan data dilakukan pada jam kerja PNS. Konsumen produk private label YOA juga didominasi oleh konsumen dengan pendapatan per bulan sebesar $\mathrm{Rp}$ 2.000.001 - Rp 5.000.000, hal ini berarti bahwa produk YOA diminati oleh pasar menengah.

Berdasarkan hasil penelitian yang dilakukan kepada 112 orang konsumen produk YOA Bandung, dapat diketahui bahwa terdapat hubungan positif antara brand image dan kepuasan pelanggan. Hal tersebut dilihat dari hasil korelasi yang diperoleh yaitu sebesar 0,387 (38,7\%) dengan arah hubungan positif. Nilai tersebut berada pada interval $+0,30$ sampai dengan $+0,49$ yang berarti terdapat hubungan positif yang sedang (Bungin, 2013: 194). Selain itu, hubungan antara brand image dan kepuasan pelanggan memiliki nilai signifikansi sebesar 0,000 yang artinya korelasi tersebut signifikan karena nilai sig < 0,05 (Sugiama, 2008: 229).

Selain itu, berdasarkan hasil analisis regresi yang telah dilakukan (Tabel 1.4), dapat diketahui bahwa antara brand image dan kepuasan pelanggan memiliki hubungan positif. Hal tersebut dapat dilihat dari persamaan regresi linear sederhana yang diperoleh, yaitu: $\mathrm{Y}=8,535+0,309 \mathrm{X}$. Nilai a dapat diartikan jika brand image nilainya sama dengan nol $(\mathrm{X}=0)$, maka nilai kepuasan pelanggan nilainya positif 8,535. Kemudian, Koefisien regresi (b) variabel brand image sebesar 0,309 yang artinya jika brand image mengalami kenaikan satu satuan maka kepuasan pelanggan akan mengalami kenaikan sebesar 0,309 satuan. Koefisien bertanda positif artinya terjadi hubungan positif antara brand image dan 
kepuasan pelanggan. Hal ini menunjukkan bahwa apabila brand image meninngkat di mata konsumen, maka kepuasan pelanggan pun akan meningkat.

Jika dilihat dari hasil koefisien determinasi (lihat tabel 1.5), brand image hanya berpengaruh sebesar $15 \%$ terhadap kepuasan pelanggan. Sementara sisanya (85\%) dipengaruhi oleh faktor-faktor lain yang tidak diteliti dalam penelitian ini. Menurut Biel (1992), faktor lain yang dapat mengukur brand image adalah corporate image dan user image. Sedangkan menurut Aaker (1991: 719), faktor lain yang dapat mengukur brand image adalah customer benefits, celebrity/person, life style/personality, product class, competitors, geographic area. Untuk variabel kepuasan pelanggan, faktor lain yang dapat mengukur kepuasan pelanggan adalah nilai-nilai individual seperti kebutuhan, keinginan, dan hasrat pembelian (Westbrook \& Reilly, 1983), pengalaman masa lalu dan pengalaman konsumen lainnya. Rendahnya nilai $\mathrm{R}$ square (15\%) menunjukkan bahwa variabel brand image memiliki pengaruh yang rendah terhadap kepuasan pelanggan.

Apabila dibandingkan dengan hasil penelitian Neupane (2015), brand image secara signifikan berpengaruh positif terhadap kepuasan pelanggan dengan persentase sebesar $88 \%$. Hal tersebut menunjukkan bahwa pengaruh yang dimiliki sangat kuat karena pasar ritel di UK sering melakukan kegiatan promosi. Berbeda dengan brand image produk YOA yang hanya memberikan pengaruh kecil terhadap kepuasan pelanggan di Toserba Griya Bandung. Hal ini dikarenakan produk YOA tidak sering melakukan kegiatan promosi. Padahal, fungsi utama dari promosi adalah sebagai media komunikasi perusahaan dengan tujuan akhir meningkatkan citra perusahaan dan memberikan informasi yang seluas-luasnya tentang manfaat produk yang dipasarkan
(Nitisusastro, 2012: 139). Selain menginformasikan produknya, promosi juga berfungsi untuk mempengaruhi dan mengingatkan pelanggan mengenai produknya (Riyono \& Budiharja, 2016: 102).

Di sisi lain, hasil penelitian ini selaras dengan beberapa penelitian sebelumnya mengenai pengaruh brand image terhadap kepuasan pelanggan. Penelitian yang dilakukan oleh Rivai \& Wahyudi (2017), Malik, et al. (2012) dan Hsiung (2011) menghasilkan bahwa terdapat pengaruh cukup kuat antara citra merek (brand image) terhadap kepuasan pelanggan dengan masing-masing persentase sebesar 33,5\%, 34\%, dan 32,2\%. Penelitian Hsiung (2011) menggunakan dimensi brand image yang berbeda dengan penelitian ini, yaitu brand value, brand characteristics dan brand association, dua diantaranya berpengaruh positf terhadap kepuasan pelanggan. Kedua dimensi yang memiliki pengaruh kuat terhadap kepuasan pelanggan adalah brand value dan brand characteristics, dengan masing masing nilai $0,322(32,2 \%)$ dan $0,247(24,7 \%)$. Hal lain diungkapkan oleh Sari (2016) yaitu meskipun brand image secara signifikan berpengaruh positif terhadap kepuasan pelanggan, namun pengaruh yang dimiliki tidak kuat atau rendah, yaitu hanya sebesar 12,4\%. Hal ini dikarenakan meskipun citra merek produk menjadi pertimbangan konsumen untuk melakukan pembelian, namun masih banyak faktor lain yang dapat mempengaruhi kepuasan pelanggan.

Untuk pengujian hipotesis, hasil yang diperoleh dari uji statistik $F$ (Tabel 1.6) dan uji statistik $t$ (tabel 1.7) menunjukkan bahwa $\mathrm{Ho}$ ditolak dan $\mathrm{Ha}$ diterima. Sehingga dapat disimpulkan bahwa brand image produk YOA berpengaruh secara signifikan terhadap kepuasan pelanggan di Toserba Griya Kota Bandung. Pada uji statistik F diperoleh nilai F hitung sebesar 19,427. Jika dibandingkan 
dengan $\mathrm{F}$ tabel, nilai $\mathrm{F}$ hitung jauh lebih besar $(19,427>3,93)$, dengan nilai signifikansi/probabilitas sebesar 0,000 . Nilai signifikansi/probabilitas tersebut menunjukkan lebih kecil dari 0,05 ( 0,000 < $0,05)$. Pada uji statistik $t$, diperoleh nilai $t$ hitung sebesar 4,408. Nilai t hitung $>\mathrm{t}$ tabel $(4,408>1,982)$ dan nilai probabilitas lebih kecil dari 0,05 $(0,000<0,05)$. Hasil tersebut menunjukkan bahwa Ho ditolak dan Ha diterima. Sehingga dapat disimpulkan bahwa brand image produk YOA berpengaruh secara signifikan terhadap kepuasan pelanggan di Toserba Griya Kota Bandung.

Citra merek memiliki peranan penting karena pelanggan selalu mencari produk atau jasa yang mereknya dapat bersaing di pasarnya (Neupane, 2015). Citra merek yang baik juga menjadi salah satu pertimbangan konsumen dalam memilih produk. Bila sebuah merek telah dikenal luas di pasaran, perusahaan tidak memerlukan usaha lebih untuk mempertahankan brand-nya. Menciptakan brand yang kuat dan positif dapat membuat konsumen merasa dan berpikir bahwa produk atau layanan yang ditawarkan lebih baik daripada pesaingnya (Andreani, 2012: 63). Merek yang sesuai dengan harapan konsumen merupakan karakteristik dari merek yang sukses, karena konsumen percaya bahwa merek tersebut dapat diandalkan setelah produk digunakan (Neupane, 2015). Persepsi pelanggan mengenai citra merek sangat penting dan dapat menentukan keberhasilan atau kegagalan dalam bisnis (Mirzai, et al, 2016: 52). Shahroudi \& Naimi (2014) menjelaskan bahwa merek yang sukses dapat meningkatkan kepercayaan konsumen dalam menggunakan produk ataupun jasa, sehingga pelanggan dapat memvisualisasikan dan mengidentifikasi produk yang diberikan. Peningkatan rasa percaya diri menandakan kepuasan konsumen terhadap produk yang dibelinya.
Terciptanya kepuasan konsumen merupakan keberhasilan yang dicapai oleh perusahaan.

Kelebihan dari penelitian ini yaitu penelitian ini berhasil membuktikan bahwa brand image produk private label YOA memberikan pengaruh terhadap kepuasan pelanggan di Toserba Griya Kota Bandung dengan persentase sebesar $15 \%$. Persentase tersebut menunjukkan bahwa variabel brand image memiliki pengaruh yang rendah terhadap kepuasan pelanggan. Sedangkan sisanya $85 \%$ dipengaruhi oleh faktor-faktor lain yang tidak dijelaskan dalam penelitian ini.

Di sisi lain, terdapat keterbatasan dalam penelitian ini, yaitu penelitian ini terbatas pada satu objek penelitian, yaitu Toserba Griya saja. Untuk penelitian selanjutnya, dapat dilakukan dengan jangkauan yang lebih luas seperti seluh anak perusahaan dari PT Akur Pratama. Selain itu, keterbatasan juga berada pada dimensi yang digunakan dalam penelitian terlalu sedikit. Sebaiknya untuk penelitian selanjutnya, dapat ditambahkan faktorfaktor lain yang tidak diteliti pada kedua variabel ini. Menurut Biel (1992), faktor lain yang dapat mengukur brand image adalah corporate image dan user image. Sedangkan menurut Aaker (1991: 719), factor lain yang dapat mengukur brand image adalah customer benefits, celebrity/person, life style/personality, product class, competitors, geographic area. Untuk variabel kepuasan pelanggan, faktor lain yang dapat mengukur kepuasan pelanggan adalah nilai-nilai individual seperti kebutuhan, keinginan, dan hasrat pembelian (Westbrook \& Reilly, 1983), pengalaman masa lalu dan pengalaman konsumen lainnya.

\section{KESIMPULAN DAN SARAN}

\section{Kesimpulan}

Berdasarkan hasil pengumpulan 
data, pengolahan data, dan analisis yang telah dilakukan untuk menjawab tujuan penelitian ini, maka dapat disimpulkan bahwa:

1. Brand image produk private label YOA berada pada kategori buruk. Dimensi favorability memiliki nilai mean tertinggi dan masuk kategori cukup. Sedangkan dimensi uniqueness memiliki nilai mean terendah dan termasuk kategori buruk. Mayoritas konsumen menilai bahwa brand image produk YOA termasuk ke dalam kategori buruk. Hal tersebut dapat dilihat dari sebagian besar indikator berada pada kategori buruk. Indikator brand image yange berada pada kategoriburuk adalah penempatan produk YOA, promosi, kualitas produk, kemasan produk, dan reputasi produk YOA. Kurangnya strategi promosi, penempatan produk YOA yang tidak strategis dan menarik perhatian, kemasan produk yang tidak menarik, kualitas produk yang buruk, dan reputasi produk YOA yang kurang baik dimata konsumen membuat brand image produk YOA tergolong kategori buruk.

2. Kepuasan pelanggan terhadap produk private label YOA berada pada kategori cukup. Dimensi ekspektasi merupakan dimensi yang memiliki nilai mean tertinggi dengan kategori cukup. Sedangkan dimensi persepsi memiliki nilai mean terendah dan termasuk kategori rendah. Kepuasan pelanggan terhadap produk private label YOA berada pada kategori rendah atau tidak puas (diskonfirmasi negatif). Hal ini terjadi karena persepsi pelanggan terhadap produk YOA lebih rendah dibandingkan dengan harapan konsumen. Sebanyak $81,3 \%$ pelanggan menyatakan tidak puas terhadap produk private label YOA

3. Korelasi antara brand image dan kepuasan pelanggan adalah 0.387 atau $38,7 \%$. Artinya terdapat hubungan positif antara brand image dengan kepuasan pelanggan searah. Bila setiap peningkatan nilai brand image maka akan diikuti oleh peningkatan kepuasan pelanggan. Terdapat pengaruh positif dan signifikan antara brand image produk private label YOA terhadap kepuasan pelanggan di Toserba Griya Bandung. Rendahnya nilai $\mathrm{R}$ square (15\%) menunjukkan bahwa variabel brand image memiliki pengaruh yang rendah terhadap kepuasan pelanggan. Sementara sisanya sebesar $85 \%$ dipengaruhi oleh faktor-faktor lain yang tidak dijelaskan dalam penelitian ini. Faktor-faktor lain yang tidak diteliti pada variabel brand image adalah seperti corporate image, penggunaan celebrity, gaya hidup konsumen, posisi merek di kelasnya (product class). Sedangkan pada variabel kepuasan pelanggan, peneliti selanjutnya dapat menambahkan faktor nilai-nilai individual, pengalaman sebelumnya, dan pengalaman konsumen lain yang mengkonsumsi produk YOA.

\section{Saran}

Berdasarkan pembahasan hasil penelitian dan kesimpulan, maka saran yang dapat diberikan terkait brand image produk private label YOA dan kepuasan pelanggan adalah:

1. Meningkatkan strategi promosi terhadap produk YOA. Strategi promosi yang dapat dilakukan adalah penggunaan iklan dan promosi penjualan. Penggunaan iklan dapat dilakukan seperti pemberian katalog produk YOA kepada masyarakat atau calon konsumen. Katalog yang dibuat harus didesain sekreatif mungkin agar dapat menarik perhatian konsumen. Selain itu juga, penggunaan iklan di jalanan seperti baliho juga dapat 
dilakukan. Sedangkan promosi penjualan yang dapat dilakukan Toserba Griya untuk meningkatkan kepuasan pelanggan terhadap produk YOA adalah pemberian kupon, potongan harga atau price packs untuk setiap pembelian produk YOA.

2. Penempatan produk YOA harus menjadi pusat perhatian konsumen. Yang dapat dilakukan perusahaan adalah adanya promosi penjualan seperti potongan harga atau tawaran "buy one get one free". Penempatan rak produk YOA disimpan di tempat yang strategis seperti dekat dengan kasir.

3. Toserba Griya Bandung sebaiknya meningkatkan citra merek (brand image) produk YOA dengan inovasi kemasan produk dibuat semenarik mungkin dan bervariasi. Kemasan dengan desain yang unik akan manarik perhatian konsumen akan meningkatkan selera konsumen untuk membeli produk.

4. Meningkatkan kualitas produk YOA karena kualitas suatu produk dipandang penting oleh konsumen dan dijadikan dasar dari pengambilan keputusan pembelian sehingga perusahaan perlu memikirkan kualitas suatu produk.

5. Toserba Griya harus meningkatkan reputasi terhadap produk YOA dengan cara memperbaiki dan meningkatkan dimensi strengthness dan uniqueness dari brand image.

6. Untuk penelitian selanjutnya perlu memperluas variabel yang diteliti, pengembangan indikator pada brand image juga perlu dilakukan. Sehingga

\section{DAFTAR PUSTAKA}

Aaker, D. (1991). Managing Brand Equity: Capitalizing on the Value of a Brand Name. New York: The Free Press
Abril, C., \& Canovas, B. R. (2016). Marketing Mix Effects on Private Labels Brand Equity. European Journal of Management and Business Economics 25, pp, 168 175.

Andreani, F., Taniaji, T. L., \& Puspitasari, R. N. (2012). The Impact of Brand Image, Customer Loyalty with Customer Satisfaction as A Mediator in Mcdonald's. Jurnal Manajemen Dan Kewirausahaan, Vol.14, No. 1, pp, 63 - 70.

Bozhinova, M. (2013). Private Label Retailers' Competitive Strategy. Global Journal of Management and Business Research Marketing Vol. 13(10), pp, 28-34.

Chen, \& Liang, C. (2009). Strategic thinking leading to private brand strategy that caters for customers' shopping preferences in retail marketing. African Journal of Business Management Vol.3 (11), pp. 741-752.

Cox, B., \& Brittain, P. (2004). Retailing An Introduction Fifth Edition. Harlow: Pearson Prentice Hall.

Dunne, D., \& Narasimhan, C. (1999). The New Appeal of Private Labels. Harvard Business Review, Vol. 77 No.3, pp, 41 - 52.

Engel, J. F., Blackwell, R. D., \& Miniard, P. W. (1995). Perilaku Konsumen Jilid 2. Jakarta: Binarupa Aksara.

Ferrinadewi, E. (2008). Merek \& Psikologi Konsumen: Implikasi pada Strategi Pemasaran. Yogyakarta: Graha Ilmu.

Foster, B. (2008). Manajemen Ritel. Bandung: Alfabeta.

Hsiung, L. C. (2011). A Study on The Relations Between The Brand Image and Customer Satisfaction in Catering Businesses. African Journal of Business Management Vol.5 (18), pp. 7732-7739. 
Indrawati. (2015). Metode Penelitian Manajemen dan Bisnis Konvergensi Teknologi Komunikasi dan Informasi. Bandung: PT Refika Aditama. Jaafar, S. N., et al. (2012). Consumers' Perceptions, Attitudes and Purchase Intention towards Private Label Food Products in Malaysia. Asian Journal of Business and Management Sciences Vol. 2 No. 8, pp. 73-90.

Keller, K., L. (1993). Conceptualizing, Measuring, and Managing Customer-Based Brand Equity. Journal of Marketing Vol 57, pp 122.

Kotler, P. (2005). Manajemen Pemasaran Jilid 1 (1 $1^{\text {th }} e d$.) (Benyamin Molan, Penerjemah). Jakarta: PT. Indeks.

Kotler, P., \& Keller, K., L. (2009). Manajemen Pemasaran Edisi 13
Jilid 1. Jakarta: Erlangga.

Kotler, P., \& Amstrong, G. (2004). Principles of Marketing. New Jersey: Pearson Education.

Kotler, P., \& Amstrong, G. (2010). Principles of Marketing Thirteenth Edition. New Jersey: Pearson Education.

Kotler, P., \& Amstrong, G. (2008). Prinsipprinsip Pemasaran Edisi 12. Jakarta: Erlangga.

Labeaga, J., Lado, N., \& Martos, M. (2007). Behavioral loyalty toward store brands. Journal Retailing Consumer Service. Vol 1 No.1, pp, $1-10$.

Liu, T., \& Wang, C. (2008). Faktors affecting attitudes toward private labels and promoted brands. Journal of Marketing Management Vol. 24, pp, 283 - 298. 